\title{
Supplementation of Moringa oleifera Leaf Meal in Layer Chickens' Feed: A Review
}

\author{
Eyayu Gobezie \\ Livestock and Fishery Research Center, Arbaminch University, P.O. Box 21, Arbaminch, Ethiopia \\ *Corresponding author's Email: gobezieeyayu@gmail.com; (DORCiD: 0000-0002-0971-2114
}

\begin{abstract}
As a dietary supplement for animals, Moringa oleifera is very useful because its leaves are very nutritious. Moringa oleifera leaves are rich in fats, proteins, vitamins, and minerals with antimicrobial effects. Leaf tea is used to treat ulcers in the stomach and diarrhea. Moringa leaves are considered healthy food sources and are recommended for anemia from malnutrition due to the high protein, fiber, and iron content of the leaves. Moringa oleifera leaves are primarily used for medicinal and human consumption purposes since they are abundant in antioxidants and other nutrients. Due to the low energy and digestibility of proteins, Moringa oleifera leaf meal supplementation increases feed intake and feed conversion ratio, as well as decreasing egg mass yield, percentage of egg production, and egg weight. More research in these areas is required to make full use of the potential advantages of the Moringa oleifera plant as layer feed.
\end{abstract}

Keywords: Layer chicken, Laying performance, Leaf meal, Moringa oleifera

\section{INTRODUCTION}

Chickens are a major and inexpensive source of animal protein, so poultry production plays a vital role in social and economic securities in developing countries (Olwande et al., 2010; Melesse et al., 2013). Nutrition and environmental factors affect the production output of poultry (Gakuya et al., 2014). Protein supplementation is very important for egg production, with the key sources being soya bean meal and fish meal (Gakuya et al., 2014).

In most developed countries, poultry production industries face the challenge of raising feed costs by $60-70 \%$ (Tesfaye et al., 2013). Modern poultry husbandry systems strive to achieve full benefit at the lowest cost of production. This situation has led to the need to look for cheap, locally available, and less competitive alternatives for some poultry feed ingredients, and in particular, protein sources (Gadzirayi et al., 2012). In this context, the best alternative protein source may be Moringa oleifera leaves.

Many parts of Moringa oleifera (leaves, fruits, immature pods, and flowers) are incorporated into typical human foods in many tropical and subtropical countries (Siddhuraju and Becker, 2003). Moringa oleifera is the supplement chosen as a leaf meal in animal diets (Siddhuraju and Becker, 2003). India, the Philippines, Ethiopia, and Sudan are widely known for the Moringa oleifera cultivation. The Moringa oleifera tree is cultivated in tropical Asia, Latin America, the Caribbean, the Pacific Islands, South Africa as well as West and East Florida (Fahey, 2005). In Ethiopia, the Moringa tree is called Shiferaw or Cabbage Tree and is usually found in the southern region.

As a feed for livestock, supplementation of Moringa oleifera is potentially beneficial, as its leaves are highly nutritious. The most nutritious components are Vitamin B complexes, Vitamin C, beta-carotene, Vitamin K, manganese, and protein, among other essential nutrients, present in Moringa oleifera leaves (Leone et al., 2015). Moringa oleifera leaves have high levels of fats, proteins, minerals, and vitamins and have antimicrobial properties (Onunkwo and George, 2015). Supplementing the diets of farm animals with Moringa oleifera was inadequate to increase production quality and health. Although Moringa oleifera has medicinal importance for the health of chickens, the supplementation of Moringa oleifera levels in the poultry diet is low due to the farmers' and producers' lack of knowledge (Mahfuz and Piao, 2019). Moringa oleifera has a high nutritional content, but there is little information on its use as a source of protein in the layer ration in poultry feeding. Consequently, data on the effects of feeding Moringa oleifera leaf meal (MOLM) is scarce when it comes to laying efficiency or egg production, egg quality and egg shelf life, chicken fertility, and hatchability (Alebachew et al., 2016). This review, therefore, intended to evaluate the role of Moringa oleifera leaf meal in layer chicken growth results.

\section{Nutritional value of Moringa oleifera}

Moringa oleifera is rich in protein, amino acids, carbohydrates, minerals, vitamins, and organic acids, and is known for its nutritional value (Raja et al., 2013). Moringa leaves have anti-bacterial, anti-inflammatory effects (Abbas et al., 
2018). Gastric ulcers and diarrhea are treated with Moringa oleifera leaf tea. Moringa leaves are safe food sources for those suffering from anemia due to malnutrition because of the high protein and fiber content and iron content (Abbas et al., 2018). The most nutritious component is the leaves of Moringa oleifera, which are an important source of Vitamin B complex, Vitamin C, beta-carotene pro-vitamin A, Vitamin K, manganese, and protein, among other essential nutrients (Mahfuz and Piao, 2019).

Compared to seeds, a greater quantity of minerals is found in Moringa oleifera leaves (Annongu et al., 2014). In reality, moringa is said to supply 7 times more vitamin $\mathrm{C}$ than oranges, 10 times more vitamin $\mathrm{A}$ than carrots, 17 times more calcium than drain, 9 times more protein than yoghurt, 15 times more potassium than bananas, and 25 times more press than spinach (Gopalakrishnan et al., 2016).

Moringa oleifera's fresh leaves contain seven times the Vitamin $\mathrm{C}$ of oranges and four times the Vitamin A of carrots. However, Moringa oleifera's dried leaves contain 10 times the Vitamin A and 1/2 times the Vitamin C of oranges (Mahmood et al., 2010). As an animal feed supplement, the leaves of Moringa oleifera are very useful as their leaves are highly nutritious. Moringa oleifera is an excellent source of vitamins and amino acids that are alleged to improve the immune system (Olugbemi et al., 2010). Moringa oleifera seeds and leaves contain all essential amino acids and, when compared to the prescribed amino acid pattern requirements for most farm animals, these are higher than sufficient amounts (Alikwe and Omotosho, 2013). The leaves of Moringa oleifera have between 16 and 19 amino acids, out of which 10 are known as essential amino acids (Sonkar et al., 2019).

Table 1. Mineral compositions of Moringa oleifera leaves (state whether these values are on a fresh or dry matter basis)

\begin{tabular}{lc}
\hline Minerals & Leaves $(\mathbf{m g})$ \\
\hline Calcium $(\mathrm{Ca})$ & 99.1 \\
\hline Phosphorous $(\mathrm{P})$ & 70.8 \\
Magnesium $(\mathrm{Mg})$ & 35.1 \\
\hline Iron $(\mathrm{Fe})$ & 1.3 \\
\hline Zinc $(\mathrm{Zn})$ & 0.85 \\
\hline Sodium $(\mathrm{Na})$ & 70 \\
\hline Manganese $(\mathrm{Mn})$ & 0.119 \\
\hline Potassium $(\mathrm{K})$ & 471 \\
\hline Reference: Abbas et al. (2018)
\end{tabular}

Table 2. Vitamin compositions of Moringa oleifera leaves and seeds

\begin{tabular}{lcc}
\hline Vitamins & Leaf & Seed \\
\hline Vitamin A (mg) & $6.3-6.8$ & $0.3-0.8$ \\
\hline Vitamin B1 (mg) & $2.59-2.64$ & $0.05-0.06$ \\
\hline Vitamin B2 (mg) & $20.5-21$ & $0.06-0.08$ \\
\hline Vitamin B3 (mg) & $8.2-9.6$ & $1.2-1.9$ \\
\hline Vitamin B5 (mg) & $0.13-1.6$ & $0.7-0.9$ \\
\hline Vitamin B9 (mg) & $39.5-40$ & $46-48$ \\
\hline Vitamin C (mg) & $17.3-19.4$ & $124-130$ \\
\hline Vitamin E (mg) & $113-121$ & - \\
\hline Reference: Chelliah et al. (2017) & &
\end{tabular}

\section{Phytochemical composition of Moringa oleifera leaf meal}

A high concentration of phytochemicals accumulates in plants, which can defend against free radical damage (Alagbe, 2019). Vitamins (A, C, and E), flavonoids, and tannins, have been found to have high levels of antioxidants, which have a variety of health benefits for humans and animals (Alagbe, 2019). The synergistic combination of these phytochemicals in Moringa oleifera causes an increase in feed intake, palatability, and disease prevention (Alagbe, 2019). A massive wide variety of bioactive compounds have been identified in Moringa oleifera (Martin et al., 2013). Vitamin-rich leaves, carotenoids, polyphenols, phenolic acids, flavonoids, alkaloids, glucosinolates, isothiocyanates, tannins, and saponins are the most commonly used parts of the plant (Leone et al., 2015). Moringa oleifera leaves are often used for medicinal and human nutrition purposes since they have high levels of antioxidants and other nutrients usually lacking in people living in undeveloped nations (Popoola and Obembe, 2013). Moringa oleifera leaves have been used to treat various diseases, ranging from malaria and typhoid fever to high blood pressure and diabetes (Sivasankari et al., 2014).

\section{Effect of Moringa oleifera leaf meal on the performance of layers}

Melesse et al. (2011) found that using Moringa stenopetala leaf meal in the diet of Rhode Island Red chicks resulted in a significant improvement $(\mathrm{p}<0.05)$ in feed and crude protein consumption, average weight gain, feed efficiency ratios, and protein efficiency ratios as compared to the control diet. As a supplement for sunflower seed meal, the addition of 10 percent and 20 percent Moringa oleifera leaf meal to the laying hen diet significantly $(p<0.05)$ increased feed intake and dry matter feed intake and decreased the development of egg mass (Kakengi et al., 2007). As the amount of Moringa oleifera leaf meal increased, the percentage of egg production decreased. The feed conversion ratio ( $\mathrm{kg} \mathrm{feed} / \mathrm{kg} \mathrm{egg}$ ) is improved when $20 \%$ Moringa oleifera leaf meal was added to the laying hen diet. At a level of $20 \%$, the addition of $5 \%$ Moringa oleifera leaf meal significantly increased egg weight $(\mathrm{p}<0.05)$ but leading to lower egg weight (Abbas, 2013)

The increase in feed intake and feed conversion ratio and the decrease in the production of egg mass, percentage of egg production, and egg weight at higher levels of Moringa oleifera leaf meal was mainly due to low energy and protein digestibility (Abbas, 2013). Olugbemi et al. (2010) noted that Moringa oleifera leaf meal supplementation had no 
significant impact on feed consumption, feed conversion ratio, and laying percentage at levels of up to $10 \%$ in a cassava chip-based diet provided to laying hens. In contrast to the control diet (free of Moringa oleifera leaf meal and cassava chip), egg weight substantially increased as a result of the supplementation of Moringa oleifera leaf meal with cassava chip (Abbas, 2013).

Abou-Elezz et al. (2011) agreed that up to $10 \%$ of the use of Moringa oleifera leaf meal had no adverse effect on laying hens' efficient output, but levels above that (15\% and 20\%) are expected to have adverse effects. Moringa oleifera leaf powder increases the number of eggs per week, egg weight, egg width, egg surface, yolk height, yolk weight, albumen weight, and yolk ratio in the layer diet of chickens by $2.5 \%$ and $5 \%$, compared to the control diet (Ebenebe et al., 2013).

\section{Effect of Moringa oleifera leaf meal on the egg quality}

There was no difference between the control groups and dietary inclusion of Moringa oleifera leaves $(p>0.05)$ in terms of the Haugh units, eggshell intensity, or egg shape index (Durmus et al., 2004). The addition of Moringa oleifera leaf had no impact on the egg shape index, which is linked to eggshell intensity and egg grade (Ebenebe et al., 2013). Mabusels et al. (2018) discovered that adding 10\% Moringa oleifera seed meal to layer diets increased shell thickness, compared to the control diet. However, both 5\% and 7.5\% Moringa oleifera seed meal supplementation had the same effect on eggshell thickness. With regard to the effect of different Moringa oleifera leaf levels on layer diet, lower levels of inclusion increased egg production and egg quality, but higher levels of inclusion resulted in lower productivity and lower quality indices in the Isa Brown Breed layer chickens (Ebenebe et al., 2013). The R2 value for the relationship between egg weight and MOL inclusion amount in the diet was 0.99. Increased MOL levels in the diet resulted in a decrease in egg weight, egg width, yolk weight, and yolk ( $p<0.05)$, but MOL had no effect on egg volume, yolk duration, yolk index, or shell weight and thickness (Raphael et al., 2015).

Increased levels of MOLM did not affect feed consumption, weight gain, customer acceptance of boiled eggs, and egg weight ( $p \geq 0.05$, Gakuya et al., 2014). In terms of the impact of different MOL levels on layer diet, MOL inclusion at lower levels improved egg production and egg quality, but higher levels of inclusion resulted in lower productivity and lower quality indices of Isa Brown Breed layers (Ebenebe et al., 2013). There was, however, no substantial difference between the eggs from MOLM diets and those from supermarkets in the egg yolk color ratings (Gakuya et al., 2014). There are no major variations in egg weights from layers of Moringa oleifera leaf and twig meals at levels ranging from $0.2 \%$ to $0.8 \%$ (Paguia et al., 2014).

Table 3. Effects of feeding various levels of Moringa oleifera leaf meal as a replacement for soya bean meal on dualpurpose of egg quality in Koekoek hens

\begin{tabular}{|c|c|c|c|c|}
\hline Moringa oleifera leaf meal incorporation & T1 (0) & T2 (5\%) & T3 (10\%) & T4 (15\%) \\
\hline Egg weight (g) & $48.66 \pm 0.36^{\mathrm{b}}$ & $54.51 \pm 0.47^{\mathrm{a}}$ & $49.94 \pm 0.91^{\mathrm{b}}$ & $50.31 \pm 0.33^{\mathrm{b}}$ \\
\hline Egg shape index & $80.92 \pm 0.56^{\mathrm{a}}$ & $75.80 \pm 0.10^{c}$ & $77.23 \pm 0.76^{\mathrm{bc}}$ & $78.79 \pm 0.25^{\mathrm{a}}$ \\
\hline Shell weight (g) & $5.67 \pm 0.33^{b}$ & $8.66 \pm 0.33^{\mathrm{a}}$ & $6.33 \pm 0.66^{\mathrm{b}}$ & $6.00 \pm 0.57^{b}$ \\
\hline Albumen weight (g) & $21.67 \pm 0.33^{\mathrm{c}}$ & $29.66 \pm 1.20^{\mathrm{a}}$ & $25.33 \pm 0.33^{\mathrm{b}}$ & $23.33 \pm 0.88^{\mathrm{cl}}$ \\
\hline Haugh unit & $75.33 \pm 0.33^{b}$ & $87.33 \pm 0.33^{\mathrm{a}}$ & $79.00 \pm 0.57^{\mathrm{b}}$ & $77.67 \pm 1.45^{\mathrm{b}}$ \\
\hline Yolk weight (g) & $15.33 \pm 0.33^{\mathrm{b}}$ & $20.66 \pm 0.33^{\mathrm{a}}$ & $17.00 \pm 1.00^{\mathrm{b}}$ & $17.33 \pm 0.33^{b}$ \\
\hline Yolk index & $0.27 \pm 0.57^{\mathrm{b}}$ & $0.34 \pm 0.33^{\mathrm{a}}$ & $0.33 \pm 0.57^{\mathrm{ab}}$ & $0.32 \pm 0.33^{\mathrm{ab}}$ \\
\hline
\end{tabular}

Reference: Tesfaye et al. (2018). Different superscript letters in a row mean statistical differences ( $\mathrm{p} \leq 0.05)$. MOLM: Moringa oleifera leaf meal, SBM: Soybean meal, T: Ration containing 0\% MOLM, T2: Ration containing 5\% MOLM, T3: Ration containing 10\% MOLM, T4: Ration containing $15 \%$ MOLM.

\section{Effect of Moringa oleifera leaf meal on fertility and hatchability}

Moringa oleifera used as an alternative feed ingredient in the layer ration showed a non-significant effect on fertility, hatchability, and embryonic mortality (Etalem et al., 2014). Moyo et al. (2011) mentioned higher levels of zinc and Vitamin E in Moringa oleifera leaf played a beneficial role in egg hatchability. Likewise, Durmus et al. (2004) noted increased hatchability with increasing zinc concentration in the diets of Brown parent stock layers. Moringa contains large amounts of iron, calcium, and phosphorus, and Vitamin C is moderately high (Agbaje et al., 2007). Adesola et al. (2012) reported improved hatchability in the diets of indigenous Venda hens as a result of ascorbic acid supplementation. However, the relatively poor hatchability and higher embryonic mortality observed in the control group may be due to a lack of critical nutrients, such as zinc and Vitamin E, which are necessary for better hatchability (Mahmood and AlDaraji, 2011). 


\section{Effects of Moringa oleifera on health status in laying hens}

In determining the health status of chickens the analysis of blood parameters is incredibly important (Mahfuz and Piao, 2019). In line with Aye and Adegun (2013), higher levels of albumin levels were observed in laying hens fed with $3 \%$ Moringa leaf meal, compared to the control group, but the number of white blood cells (WBCs), red blood cells, lymphocytes, and packed cell volume were lower than the control diets in Moringa-fed groups. The antimicrobial activity of the phytochemicals in Moringa leaves may be attributed to the fact that Moringa-fed chickens have fewer WBCs and lymphocytes. A high WBC count is commonly linked to an infection caused by bacteria in the host (Mahfuz and Piao, 2019). The findings of this study indicated that Moringa pod meal supplementation was found to have lower serum cholesterol levels (Mahfuz and Piao, 2019). Lower plasma levels of malondialdehyde (MDA) and higher glutathione peroxidase have been linked to higher antioxidant activity in laying hens fed Moringa leaf meal (Lu et al., 2016). Plasma total protein levels were dietary 5\% higher after Moringa leaf meal supplementation, which is a good predictor of liver synthetic activity. Furthermore, lower plasma uric acid indicated that supplemented laying hens retained more protein (Lu et al., 2016). Increased antioxidant enzyme activity and lower MDA levels in plasma and egg yolks indicated that Moringa supplementation could improve antioxidant activity and Moringa oleifera has strong phytobiotic properties.

\section{CONCLUSION}

In developing countries, poultry production plays a significant socio-economic role since chickens are an important and inexpensive source of animal protein. As a feed for livestock, supplementation of Moringa oleifera is potentially beneficial and its leaves are highly nutritious. The most nutritious components are Vitamin B complexes, Vitamin C, beta-carotene, Vitamin K, manganese, and protein, among other essential nutrients that are present in Moringa oleifera leaves. The increase in feed intake and feed conversion ratio and the decrease in the production of egg mass, percentage of egg production, and egg weight at higher levels of Moringa oleifera leaf meal were mainly due to low energy and protein digestibility. The effect of different Moringa oleifera leaf levels on layer diet, lower levels of inclusion increased egg production and egg quality, but higher levels of inclusion resulted in lower productivity and lower quality indices in the Isa Brown Breed layer chickens. Moringa oleifera leaves are mostly used both for medicinal and human nutrition purposes since they are rich in antioxidants and other nutrients, which are usually deficient in people living in undeveloped countries. More research in these areas is required in order to make full use of the potential advantages of the Moringa oleifera plant as layer feed.

\section{DECLARATIONS}

\section{Competing interests}

None.

\section{Ethical considerations}

All ethical issues (including plagiarism, double publication and/or submission, and redundancy) have been checked and approved by the author.

\section{REFERENCES}

Abbas RK, Elsharbasy FS, and Fadlelmula AA (2018). Nutritional values of Moringa oleifera, total protein, amino acid, vitamins, minerals, carbohydrates, total fat and crude fiber, under the semi-arid conditions of Sudan. Journal of Microbial Biochemical Technology, 10: 56-58. DOI: https://www.doi.org/10.4172/1948- 5948.1000396

Abbas TE (2013). The use of Moringa oleifera in poultry diets. Turkish Journal of Veterinary and Animal Sciences, 37: 492-496. DOI: https://www.doi.org/10.3906/vet-1211-40

Abou-Elezz FMK, Sarmiento-Franco L, Santos-Ricalde R, and Solorio-Sanchez F (2011). Nutritional effects of dietary inclusion of Leucaena leucocephala and Moringa oleifera leaf meal on Rhode Island Red hens' performance. Cuban Journal of Agricultural Science, 45: 163-169. Available at: http://cjascience.com/index.php/CJAS/article/view/137

Adesola A, Ng'ambi J, and Norris D (2012). Effect of ascorbic acid supplementation level to diets of indigenous Venda hens on egg production, hatchability and subsequent productivity of chicks. African Journal of Biotechnology, 11: 1260-1261. Available at: https://www.ajol.info/index.php/ajb/article/view/129059

Agbaje G, Tayo O, Chioma G, and Ajomale K (2007). Evaluation of yellow-rooted cassava varieties for differences in $\beta$-carotene and gross energy. Journal of Applied Sciences Research, 3: 946-948. Available at: https://publication.babcock.edu.ng/asset/docs/publications/AGRI/9511/2301.pdf

Alagbe J (2019). Role of Moringa olifera leaf meal on the growth performance of poultry/African catfish-a review. International Journal of Advanced Biological and Biomedical Research, 7(3): 237-245. Available at: http://www.ijabbr.com/index.php/journal/article 34924.html

Alebachew W, Tesfaye E, and Tamir B (2016). Effects of different dietary levels of Moringa oleifera Leaf meal on egg production, quality, shelf life, fertility and hatchability of dual purpose koekoek hens. Addis Ababa University, Ethiopia, MSc, thesis. Middle-East Journal of Scientific Research, 24(9): 2909-2920. DOI: http://www.doi.org/10.5829/idosi.mejsr.2016.24.09.23907

Alikwe PCN, and Omotosho MS (2013). An evaluation of the proximate and phytochemical composition of Moringa oleifera leaf meal as potential feedstuff for non-ruminant livestock. Agrosearch, 13(1): 17-27. DOI: http://www.doi.org/1010.4314/agrosh.v13i1.2 
Annongu A, Karim OR, Toye AA, Sola-Ojo FE, Kayode RMO, Badmos AHA, Alli OI, and Adeyemi KD (2014). Geo-assessment of chemical composition and nutritional evaluation of Moringa oleifera seeds in nutrition of broilers. Journal of Agricultural Science, 6(4): 119-124. DOI: http://www.dx.doi.org/10.5539/jas.v6n4p119

Aye PA, and Adegun MK (2013). Chemical composition and some functional properties of Moringa, Leucaena and Gliricidia leaf meals. Agriculture and Biology Journal of North America, 4(1): 71-77. DOI: http://www.doi.org/10.5251/abjna.2013.4.1.71.77

Chelliah R, Ramakrishnan S, and Antony U (2017). Nutritional quality of Moringa oleifera for its bioactivity and antibacterial properties. International Food Research Journal, 24: 825-833. Available at: http://www.ifrj.upm.edu.my/24\%20(02)\%202017/(50).

Durmus I, Atasoglu C, Mizrak C, Ertas S, and Kaya M (2004). Effect of increasing zinc concentration in the diets of Brown parent stock layers on various production and hatchability traits. Archives Animal Breeding, 5: 483-489. DOI: https://www.doi.org/10.5194/aab-47-483-2004

Ebenebe CI, Anigbogu CC, Anizoba MA, and Ufele AN (2013). Effect of various levels of Moringa leaf meal on egg quality of Isa Brown Breed of layers. Advances in Life Science and Technology, 14: 45-49. Available at: https://iiste.org/Journals/index.php/ALST/article/viewFile/8612/8809

Etalem T, Getachew A, Mengistu U, and Tadelle D (2014). Cassava root chips and Moringa oleifera leaf meal as alternative feed ingredients in the layer ration. Journal of Applied. Poultry Research, 23(4): 614-624. DOI: http://www.doi.org/10.3382/japr.2013-00920

Fahey JW (2005). Moringa oleifera. A review of the medical evidence for its nutritional, therapeutic and prophylactic properties. Trees for Life Journal, 1(5): 1-15. Available at: http://www.TFLJournal.org/article.php/20051201124931586

Gadzirayi CT, Masamha B, Mupangwa JF, and Washaya S (2012). Performance of broiler chickens fed on mature Moringa oleifera leaf meal as a protein supplement to soybean meal. International Journal of Poultry Science, 11(1): 5-10. DOI: http://www.doi.org/10.3923/ijps.2012.5.10

Gakuya DW, Mbugua PN, Mwaniki SM , Kiama SG, Muchemi GM, and Njuguna A (2014). Effect of supplementation of Moringa oleifera (LAM) leaf meal in layer chicken feed. International Journal of Poultry Science, 13(7): 379-384. DOI: http://www.doi.org/10.3923/ijps.2014.379.384

Gopalakrishnan L, Kruthi D, and Devarai K (2016). Moringa oleifera: A review on nutritive importance and its medicinal application. Food Science and Human Wellness, 5(2):49-56. DOI: https://www.doi.org/10.1016/j.fshw.2016.04.001

Kakengi AMV, Kaijage JT, Sarwatt SV, Mutayoba SK, Shem MN, and Fujihara T (2007). Effect of Moringa oleifera leaf meal as a substitute for sunflower seed meal on performance of laying hens in Tanzania. Livestock Research for Rural Development, 19(8): Article \#120. Available at: http://www.lrrd.org/lrrd19/8/kake19120.htm

Leone A, Spada A, Battezzati A, Schiraldi A, Aristil J, and Bertoli S (2015). Cultivation, genetic, ethnopharmacology, phytochemistry and pharmacology of Moringa oleifera leaves: An overview. International Journal of Molecular Sciences, 16: 12791-12835. DOI: http://www.doi.org/10.3390/ijms160612791

Lu W, Wang J, Zhang HJ, Wu SG, and Qi GH (2016) Evaluation of Moringa oleifera leaf in laying hens: Effects on laying performance, egg quality, plasma biochemistry and organ histopathological indices. Italian Journal of Animal Science, 15(4): 658-665. DOI: https://www.doi.org/10.1080/1828051X.2016.1249967

Mabusels SP, Nkukwana TT, Mokoma M, and Muchenje V (2018). Layer performance, fatty acid profile and the quality of eggs from hens supplemented with Moringa oleifera whole seed meal. South African Journal of Animal Science, 48(2): 235-243. DOI: http://www.dx.doi.org/10.4314/sajas.v48i2.4.

Mahfuz S, and Piao XS (2019). Review on application of moringa (Moringa oleifera) as natural feed supplement in poultry diets. A review. Animals, 9: Article number 431. DOI: http://www.doi.org/10.3390/ani9070431

Mahmood H, and Al-Daraji H (2011). Effect of dietary supplementation with different levels of zinc on sperm egg penetration and fertility traits of broiler breeder chicken. Pakistan Journal of Nutrition, 10: 1083-1088. DOI: http://www.doi.org/10.3923/pjn.2011.1083.1088

Mahmood KT, Mugal T, and Ul Haq I (2010). Moringa oleifera: A natural gift-A review. Journal of Pharmaceutical Sciences and Research, 2(11): 775-781. Available at: https://citeseerx.ist.psu.edu/viewdoc/download?doi=10.1.1.193.7882\&rep=rep1\&type=pdf

Martin C, Martin G, Garcia A, Fernández T, Hernández E, and Puls L (2013). Potential applications of Moringa oleifera. A critical review. Pastosy Forrajes, 36: 150-158. Available at: http://scielo.sld.cu/scielo.php?script=sci_abstract\&pid=S086403942013000200001\&lng=es\&nrm=iso\&tlng=en

Melesse A, Getye Y, Berihun K, and Banarjee S (2013). Effect of feeding graded levels of Moringa stenopetala leaf meal on growth performance, carcass straits and some serum biochemical parameters of Koekoek chickens. Livestock Science, 157: 498-505. http://www.dx.doi.org/10.1016/j.livsci.2013.08.012

Melesse A, Tiruneh W, and Negesse T (2011). Effects of feeding Moringa stenopetala leaf meal on nutrient intake and growth performance of Rhode Island Red chicks under tropical climate. Tropical and Subtropical Agro ecosystems, 14: 485-492. Available at: https://www.revista.ccba.uady.mx/ojs/index.php/TSA/article/view/876

Moyo B, Masika PJ, Hugo A, and Muchenje V (2011). Nutritional characterization of Moringa (Moringa oleifera Lam.) leaves. African Journal of Biotechlogy, 10(60): 12925-12933. DOI: http://www.doi.org/10.5897/AJB10.1599

Olugbemi TS, Mutayoba SK, and Lekule FP (2010). Effect of Moringa (Moringa oleifera) inclusion in cassava based diets fed to broilers chickens. International Journal of Poultry Science, 9: 363-367. DOI: http://www.doi.org/10.3923/ijps.2010.363.367

Olwande PO, Ogara WO, Okuthe SO, Muchemi G, Okoth E, Odindo MO, and Adhiambo RF (2010). Assessing the productivity of indigen ous chickens in an extensive management system in southern Nyanza, Kenya. Tropical Animal Health and Production, 42: 283-288. DOI: http://www.doi.org/10.1007/s11250-009-9418-4

Onunkwo DN, and George OS (2015). Effects of Moringa oleifera leaf meal on the growth performance and carcass characteristics of broiler birds Journal of Agriculture and Veterinary Sciences, 8: 63-66. DOI: http://www.doi.org/10.9790/2380-08326366

Paguia M, Rina Q, Paguiab, Balbac C, and Floresd RC (2014). Utilization and evaluation of Moringa oleifera L. as poultry feeds. APCBEE Procedia, 8: 343-347. DOI: http://www.doi.org/10.1016/j.apcbee.2014.03.051

Popoola JO, and Obembe OO (2013). Local knowledge, use pattern and geographical distribution of Moringa oleifera Lam. (Moringaceae) in Nigeria. Journal of Ethnopharmacology, 150: 682-691. DOI: http://www.doi.org/10.1016/j.jep.2013.09.043

Raja S, Bagle BG, and More TA (2013). Drumstick (Moringa oleifera Lamk.) improvement for semiarid and arid ecosystem: Analysis of environmental stability. Journal of Plant Breeding and Crop Science, 5(8): 164-170. DOI: http://www.doi.org/10.5897/JPBCS12.029

Raphael KJ, Christian KT, Juliano RS, Lisita F, Soultan MY, Hervé MK, and Alexis T (2015). Effects of substituting soybean with Moringa oleifera meal in diets on laying and eggs quality characteristics of KABIR chickens. Journal of Animal Research and Nutrition, 1: 4. DOI: https://www.doi.org/10.21767/2572-5459.100004

Siddhuraju P, and Becker K (2003). Antioxidant properties of various solvent extracts of total phenolic constituents from three different agro-climatic origins of drumstick tree (Moringa oleifera Lam.). Journal of Agricultural and Food Chemistry, 15: 2144-2155. DOI: http://www.doi.org/10.1021/jf020444 
Sivasankari B, Anandharaj M, and Gunasekaran P (2014). An ethnobotanical study of indigenous knowledge on medicinal plants used by the village peoples of Thoppampatti, Dindigul district, Tamilnadu, Indian Journal Of Ethnopharmacology, 153: 408-423.DOI: http://www.doi.org/10.1016/j.jep.2014.02.040

Sonkar N, Singh N, Santra AK, Mishra S, Verma LP, and Soni A (2019). Application of munga (Moringa oleifera) in livestock feed: A review. International Journal of Chemical Studies, 8(1): 1729-1735. DOI: https://www.doi.org/10.22271/chemi.2020.v8.i1y.8513.

Tesfaye E, Alebachew W, and Tamir B (2018). Performance of koekoek chicken fed with different levels of Moringa oleifera leaf meal. Journal of Animal Science and Research 2(3): 1-9. DOI: http://www.dx.doi.org/10.16966/2576-6457.115

Tesfaye E, Animut G, Urge M, and Dessie T (2013). Moringa oleifera leaf meal as an alternative protein feed ingredient in broiler ration. International Journal of Poultry Sciences, 12(5): 289-297. DOI: http://www.doi.org/10.3923/ijps.2013.289.297 